\title{
Morphological analysis of three wound-cleaning processes on potentially contamined wounds in rats ${ }^{1}$
}

\author{
Análise morfológica de três tipos de limpeza em feridas cutâneas potencialmente \\ infectadas em ratos
}

\author{
Armando José d‘Acampora², Daniella Serafin Couto Vieira³, Marcos Túlio Silva', Débora Cadore de Farias ${ }^{5}$, Ricardo Tramonte \\ 1. Research performed at Surgical Technique and Experimental Surgery of the Federal University of Santa Catarina (UFSC), Brazil. \\ 2. Associate Professor, PhD, Department of Surgery, UFSC, Brazil. \\ 3. Assistant Professor, MSc, Department of Pathology, UFSC, Brazil. \\ 4. Assistant Professor, MSc, Department of Anatomy, UFSC, Brazil. \\ 5. Graduate Student, UFSC, Brazil. \\ 6. Associate Professor, PhD, Department of Morphological Sciences, UFSC, Brazil.
}

\begin{abstract}
Purpose: To evaluate the inflammatory response of potentially infected wounds treated with isotonic saline solution, chlorhexidine and PVP-I, seven days after surgery. Methods: Thirty-two male rats were used, divided into 4 groups. All animals had their surgical wounds infected with a standard bacterial inoculum. Control group (A): animals had their surgical wounds sutured without any kind of cleaning. Saline solution group (B): animals had their wounds cleaned with saline solution. Chlorhexidine group (C): animals had their wounds cleaned with chlorhexidine. PVP-I group (D): animals had their wounds cleaned with PVP-I. Seven days after surgery, all the animals had their skin submitted to microscopic and macroscopic evaluation. Results: Edema was found on all histological slices analyzed, as well as vascular proliferation and congestion. Groups A and D showed presence of mild neutrophilic infiltrate, and moderate lymphocytic and macrophage infiltrate. Group B showed severe neutrophilic, macrophage, and lymphocytic infiltrate. Group C showed moderate neutrophilic, macrophage, and lymphocytic infiltrate. Conclusion: Group D was the group which showed inflammatory infiltrate most similar to the group that was not submitted to treatment.
\end{abstract}

Key words: Antisepsis. Chlorhexidine. Povidone-Iodine. Wounds and Injuries.

\section{RESUMO}

Objetivo: Avaliar a resposta inflamatória da limpeza de feridas potencialmente infectadas tratadas com PVP-I, clorexidina e solução salina isotônica, no sétimo dia de pós-operatório, em ratos Wistar. Métodos: Utilizou-se 32 ratos distribuídos em quatro grupos. Os animais tiveram suas feridas operatórias infectadas com um inóculo bacteriano padrão. Grupo controle (A): os animais tiveram suas feridas operatórias suturadas sem a limpeza com qualquer substância. Grupo solução salina (B): os animais tiveram suas feridas operatórias lavadas com solução salina. Grupo Clorexidina (C): os animais tiveram suas feridas operatórias lavadas com clorexidina. Grupo PVP-I (D): os animais tiveram suas feridas operatórias lavadas com PVP-I. Após sete dias foi realizada a avaliação morfológica da pele. Resultados: Em todos cortes histológicos observou-se a presença de edema, proliferação e congestão vascular. O grupo A e D mostraram a presença de um infiltrado neutrofílico discreto, macrofágico e linfocítico moderados. O grupo B, um infiltrado neutrofílico, macrofágico e linfocítico severos. O grupo C, um infiltrado de neutrófilos, macrófagos e linfócitos em moderada quantidade. Conclusão: O grupo D foi o grupo que apresentou o infiltrado inflamatório mais semelhante com o grupo que não recebeu nenhum tratamento.

Descritores: Anti-Sepsia. Clorexidina. Povidina-Iodo. Ferimentos e Lesões.

\section{Introduction}

Wound healing consists of a perfect and coordenate cascade of cellular and molecular events which interact to promote the repavement and reconstitution of the damaged tissue. ${ }^{1}$ Since the origins of medicine there has been a concern about the healing of wounds in general, considered to be essential to life, as it has always been known that infections acquired through wounds might lead to death. ${ }^{2}$ A great example of such ancient concern is Edwin Smith's papyrus, the oldest medical document ever known (Egypt, 5000 b.C.), which is famous for providing guidance on the treatment of infections contained therein.,4 During the Second World War, the treatment and healing of wounds focused on the utilization of antiseptic and topical agents with antimicrobial action and protection with dry covers, a 
result of Pasteur's findings on the Theory of Germs. These were the golden years with regards to the utilization of antiseptics such as Dakin, Eusol, iodine, mercury and aluminum products. ${ }^{1}$ Nowadays, infection continues to be a major concern. The solution of skin continuity caused by the injury allows for both residing and transitory microorganisms to multiply, duplicating themselves every two hours after the injury, thus causing a local infection. There are also the microorganisms of the surfaces which the wound came in contact with, which may also infect it ${ }^{5}$, becoming one more interference that is likely to delay the scarring process. Based on these findings, some authors propose a didatic classification to healing, dividing the process into five main stages ${ }^{1}$ :

1. Coagulation - dependent on platelet activity and on the coagulation cascade, in which the formation of a clot takes place, with the purpose of coapting the wound edges and crossing fibronectin, thus offering a provisional matrix through which fibroblasts, endothelial cells and keratinocytes can enter the wound.

2. Inflammation - dependant on both inflammatory mediators and inflammatory cells such as polymorphonuclear leucocytes (PMN), macrophages and lymphocytes. The PMNs arrive at the time when tissue damage occurs and remain from tree to five days, being responsible for bacterial phagocytosis. The macrophage remains from the third to the 10th day, promoting phagocytosis of bacteria and foreign bodies, directing the development of granulation tissue. Lymphocytes appear in the wound within seven days, having major influence on macrophages. Fibronectin, synthetized by fibroblasts, keratinocytes and endothelial cells, adheres simultaneously to fibrin, collagen and other cell types as if it were some glue, thus consolidating the fibrin clot, the cells and the matrix components. Due to its chemotactic properties, fibronectin promotes the opsonization and phagocytosis of foreign bodies and bacteria, being an important component of this stage.

3. Proliferation - It is the synthesis of the injury itself. It presents tree sub-stages.

3.1. re-epithelialization, in which there will be a migration of undamaged keratinocytes from the wound edges and epithelial annexes, with epithelial hyperplasia.

3.2. fibroplasia and matrix formation, important in the formation of granulation tissue (collection of cellular elements, including fibroblasts, inflammatory cells, neovascular and matrix components, such as fibronectin, glycosaminoglycans and collagen). The formation of granulation tissue depends on the fibroblast, a critical cell in the matrix formation as it produces collagen, elastin, fibronectin, glycosaminoglycan and protease, responsible for physiological debridement and re-modelling.

3.3. angiogenesis, in which endothelial cells migrate to the injured area, proliferate and determine the way for other cells that are responsible for the healing process.
4. Wound contraction - centripetal movement of fullthickness wound edges. Partial-thickness edges (incomplete corium injury) do not carry out this stage.

5. Remodelling - occurs throughout months and is responsible for tensional strength and for reducing scar and erythema size, taking place in the collagen and matrix.

On a routine basis, an adequate and careful mechanical cleaning of the wound is done prior to any necessary problem-solving procedure. The way in which such cleaning is to be done, however, still remais controversial among emergency professionals and the same holds true for the

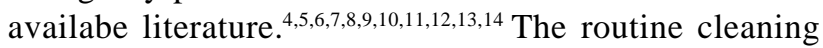
procedure of any wound prior to suture varies from hospital to hospital. Most medical services use a chlorhexidine or a poplyvinylpyrrolidine (PVP-I) solution for woundcleaning ${ }^{9,10,11,12}$ while others use only a saline solution at $0.9 \%$ to do the cleaning. In our service, cleaning with soap and water is thought to be the simplest, most inexpensive and rather efficient way to do it, which any service can afford. In the consulted literature on substances used in the antisepsis of wounds, contradictory results were found, mainly with regards to the use of chlorhexidine and PVP-I. De Wet et $\mathrm{al}^{15}$ verified the bactericidal effect of PVP-I in the form of ointment in the treatment of burns and concluded that it had not been satisfactory in the group studied..$^{15}$ Molloy and Brady ${ }^{10}$ stated that the use of PVP-I inhibits wound healing in an experimental rat model, but does not mention the inflammatory reaction and the presence of tissue necrosis. ${ }^{10}$ In a similar line of investigation, Kjolseth et al $^{11}$ proved that PVP-I delays wound epithelialization when compared to sodium hypochlorite, silver sulphadiazine, bacitracine and silver nitrate. However, these researchers did not comparatively study chlorhexidine, which is widely used in Brazilian hospitals. ${ }^{11}$ Kashyap et al $^{12}$ concluded that PVP-I reduces wound strength ${ }^{12}$ and, in an experimental study, could not demonstrate its superior action when compared to an isotonic saline solution. ${ }^{16}$ More recently, Souza Filho et $\mathrm{al}^{2}$, using an animal model, evaluated the use of the isotonic saline solution compared to agar in the treatment of wounds infected with Staphylococcus aureus, in which the latter proved to be more regular and efficient than the saline solution. Most authors agree that PVP-I reduces wound infection and also that it delays healing, but no comparative experimental histological study could be found on chlorhexidine, PVP-I and the saline solution which showed the tissue reactions resulting from their individualized utilization on wounds. . $^{2,10,11,12,17,18}$

Several products have been experimentally tested in order to obtain the ideal substance to reduce tissue infection without altering the healing process, but there is still no

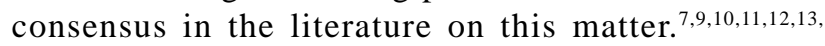
14,18,19,20,21,22,23 Therefore, this experimental study has been proposed with the purpose of comparing both macroscopically and microscopically the inflammatory reactions caused by each of the substances being studied on the cleaning of potentially infected wounds, in order to evaluate the inflammatory response of their treatment with polyvynilpyrrolidine (PVP-I), chlorhexidine and isotonic saline solution, in the seventh day post-operatory, on Wistar rats. 


\section{Methods}

The experiment was conducted in the Operatory Technique and Experimental Surgery Laboratory of the Clinical Surgery Department at the Federal University of Santa Catarina. This research was approved to Ethical Animal Committee of UFSC. Thirty-two male rats of the Rattus norvergiccus species, Wistar strain, with the average age of 120 days, coming from the Central Vivarium of the Federal University of Santa Catarina. The animals were fed appropriately for the species, having free access to food and water throughout the experiment, being kept under ambient temperature, light and noise, maintaining the daynight cycle in plastic cages. Each cage contained only one animal, isolated from the forrage by a stainless steel screen, without any contact with its physiological secretions (urine and feces). The animals were distributed into four groups:

\section{Control group - Group A $(n=8)$}

The animals in this group had a wound produced on their dorsal region and infected with the standard inoculum and, after 15 minutes, had the incision sutured without any wound cleaning. After seven days, they were submitted to euthanasia and a skin fragment was collected, as will be described later, and sent for a morphological analysis.

\section{Saline solution group - Group B $(n=8)$}

The animals in this group had a wound produced on their dorsal region and infected with the standard inoculum and, after 15 minutes, had the incision washed with $100 \mathrm{ml}$ isotonic saline solution at $0.9 \%$ and sutured with a monofilament thread. After seven days, they were submitted to euthanasia and a skin fragment was collected, as will be described later, and sent for a morphological analysis.

\section{Chlorhexidine group - Group C ( $n=8)$}

The animals in this group had a wound produced on their dorsal region and infected with the standard inoculum and, after 15 minutes, had the incision washed with five ml chlorhexidine in degerming solution at $2 \%$ and $100 \mathrm{ml}$ saline solution at $0.9 \%$ and sutured with a monofilament thread. After seven days, they were submitted to euthanasia and a skin fragment was collected, as will be described later, and sent for a morphological analysis.

\section{PVP-I group - Group D $(n=8)$}

The animals in this group had a wound produced on their dorsal region and infected with the standard inoculum and, after 15 minutes, had the incision washed with five ml polyvinylpylorridine in a degerming solution at $10 \%$ and $100 \mathrm{ml}$ saline solution at $0.9 \%$ and sutured with a monofilament thread. After seven days, they were submitted to euthanasia and a skin fragment was collected, as will be described later, and sent for a morphological analysis. The cages had alpha numeric identification, the animals being numbered one-eigth in each group.

\section{Procedures}

The inoculum was obtained from Staphylococcus aureus and Streptococcus pyogenes colonies provided by Santa Luzia Medical Laboratory, obtained from microbiological examinations carried out by this laboratory. These cultures were transferred to a culture environment called Miller-Hinton, placed on Petry dishes and kept in the laboratory by successive striking for suspension in a Sodium Chloride aqueous solution at $0.9 \%$, in the amount of $10^{9}$ bacteria per $\mathrm{ml}$ of suspension, amount considered to be infectant in $100 \%$ of cases, measured by means of a Mac Farland scale, read against the light collorimeter. The bottles were individualized with one $\mathrm{ml}$ of suspension each, and frozen at $-70^{\circ} \mathrm{C}$. The bottles were defrosted in the immediate pre-operatory in boiling water at $37^{\circ} \mathrm{C}$. All animals, already identified and weighed, were submitted to anesthesia with a solution containing Ketamine Hydrochloride and aqueous solution at $2 \%$ of 2 -Hydrochloride -(2, 6-xylidine)- 5, 6dihydro-4-H-1,3-tiazine at the rate of $5: 1,0,5 \mathrm{ml}$ of the solution being injected in the intramuscular way, on the inside of the animal's left leg, previously chosen by drawing. Following anesthesia, the animals were immobilized and placed on a $30 \times 35 \mathrm{~cm}$ wooden board, protected by a one cm-thick styrofoam sheet and tied on their paws and legs with rubber bands in the horizontal position lying on their bellies. Depilation was done by means of pulling on the animal's dorsal region, in an area of approximately eigth $\mathrm{cm}^{2}$, without any chemical antisepsis, only washing with two ml saline solution at $0.9 \%$. Every animal was submitted to a tree $\mathrm{cm}$ incision in the median dorsal region and had the fullthickness wound produced, sectioning full corium and subcutaneous cellular tissue, later infected with one $\mathrm{ml}$ of each bacterial inoculum already described ${ }^{24,25}$, first Streptococcus pyogenes and then Staphylococcus aureus, such sequence being defined by drawing (Figures 1 a 4). The same bacterial strains were used for all animals in the experiment. The inoculum was previously tested and the preliminary study showed that infection occured in $100 \%$ of untreated wounds after five days. ${ }^{24,25}$ Surgical procedures were carried out with aseptic technique and at an average temperature of 28 degrees centigrade, with the support of an air conditioner.

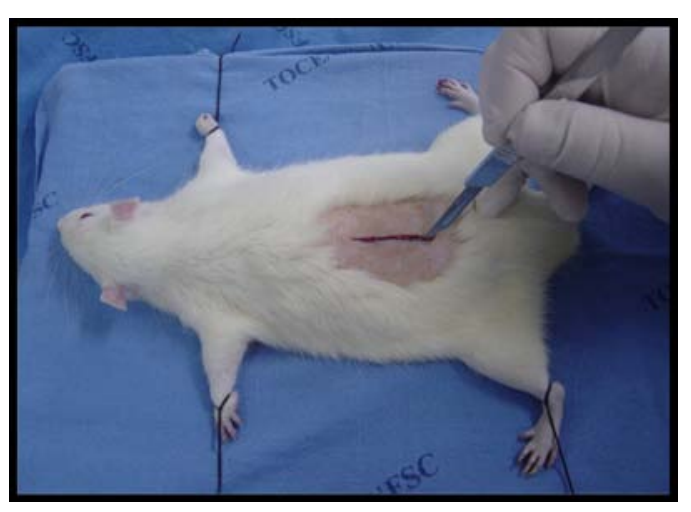

FIGURE 1 - Picture showing $3 \mathrm{~cm}$-incision on animal's dorsum. 


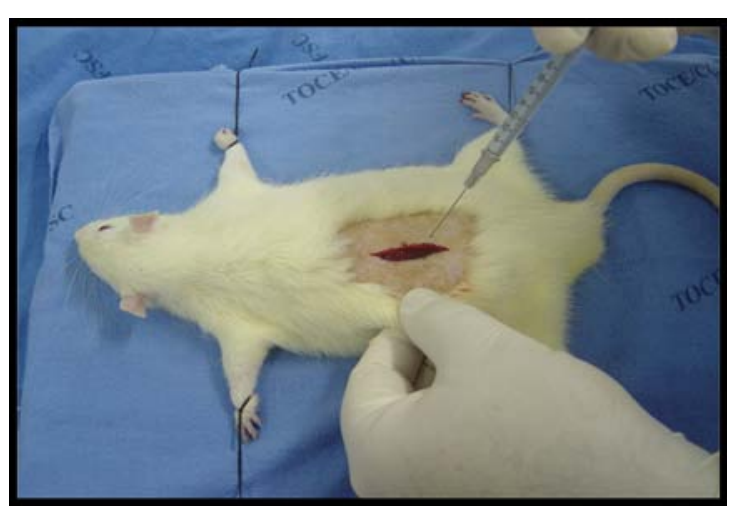

FIGURE 2 - Picture showing wound being contaminated with $1 \mathrm{ml}$ of inoculum .

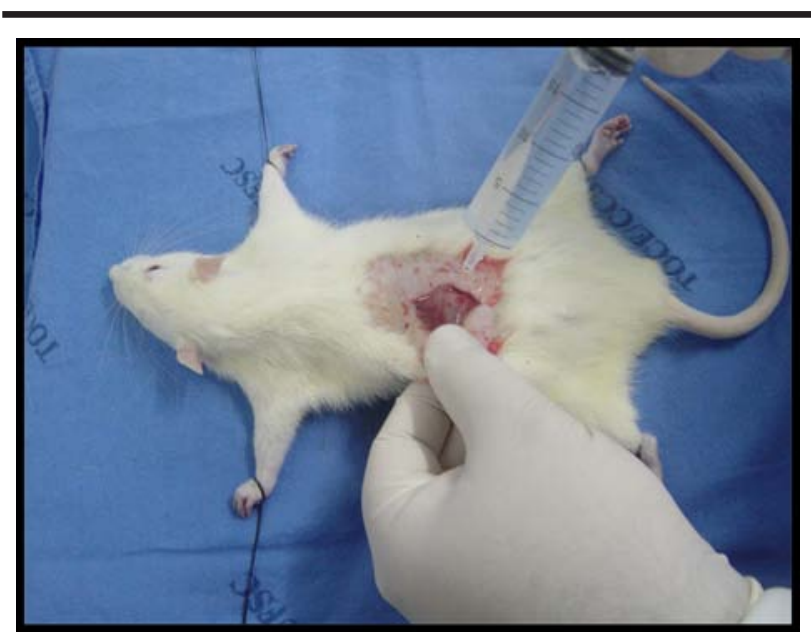

FIGURE 3 - Picture showing wound being cleaned saline solution.

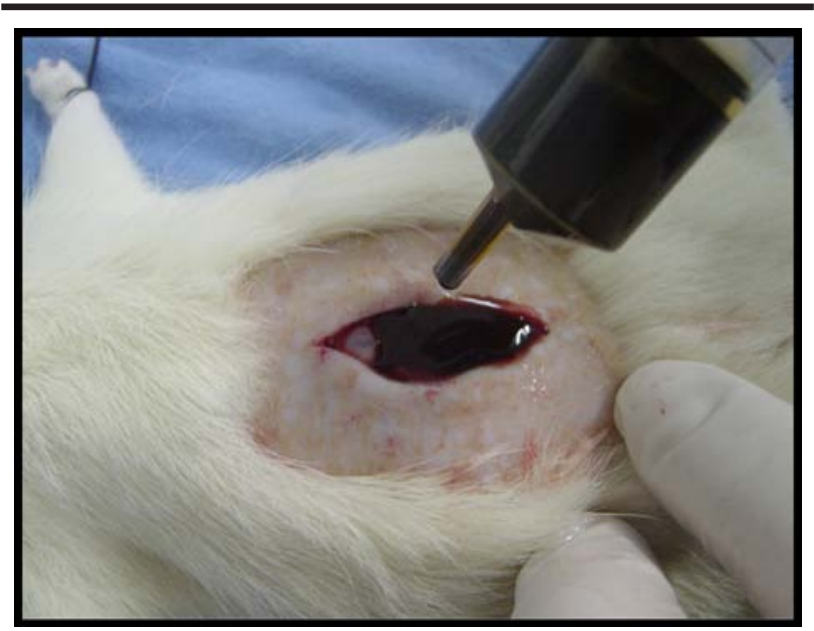

FIGURE 4 - Picture showing wound being cleaned with with PVP-I.

Fifteen minutes after the wound was infected by the described bacterial strain, the animals had their wounds washed by one of the substances being studied, which have been previously described, followed by wound synthesis with Mononylon ${ }^{\circledR}$ 4-0 thread in separate stitches on a single plan, comprising subcutaneous cellular tissue and skin. As to the animals in the control group, they only had their wounds sutured in the manner described above, but without any prior washing. All animals in all groups had the same number of stitches done, two stitches. No occlusive dressing was placed on the surgical wound. A daily follow-up was conducted in the post-operatory with the purpose of indentifying probable inflammatory and infectious reactions. The following parameters were used for wound analysis:

a. Alteration on skin color. b. Observation and notetaking of secretion present in the wound as to type, odor, color, and presence or not of purulent material.

No analgesia and no dressing was used in the postoperatory of the animals being srudied. Animals were submitted to euthanasia by a lethal dose of ethylic ether and were placed on a 35x30 cm wooden board lying on their bellies. A 4x2 cm skin sample was taken from the region where the procedure had been done, which was then sent for a hystopathological analysis. The skin fragments were fixed in an aqueous formaldehyde solution at $10 \%$ and sent to the Anatomico-Pathological Diagnostic Institute - IDAP - Pathology Laboratory at the Caridade Hospital in Florianópolis, SC. The specimens were submitted to the usual hystological processing with dehydration and clarification in a tissue processor (PT MONO 200®), being later included in paraffin blocks, identified and sectioned in microtome with five semi-seriate slices with a thickness of tree micrometers $(\mu \mathrm{m})$. The slide blades obtained were indentified with the protocol number and stained with Hematoxilin-Eosin. All slide blades were evaluated by the same researcher in a Nikon Elipse $200 \AA$ microscope with $4 \mathrm{X}$ e $40 \mathrm{X}$ lenses, with enlargements of $40 \mathrm{X}$ and $400 \mathrm{X}$ respectively. The parameters used for microscopic evaluation were:

a. Presence or not of edema

b. Presence or not of vascular proliferation

c. Presence or not of vascular congestion

d. Presence or not of neutrophilic infiltrate, classifying it, when present, into mild, moderate and severe

e. Presence or not of macrophage, classifying it, when present, into mild, moderate and severe

f. Presence or not of lymphocytic infiltrate, classifying it, when present, into mild, moderate and severe

g. Presence or not of young fibrosis

h. Presence or not of granulation tissue

i. Presence or not of fibroblast proliferation

j. Presence or not of foreign body granuloma

The data obtained were submitted to statistical analysis employing EpiData and EpiInfo programs and considered to be significant when $\mathbf{p} \leq 0,05$.

\section{Results}

Out of the 32 animals in the experiment, none came to die within seven days following the first surgical procedure. Wound examination with unarmed eye, which took place from the first to the seventh postoperative day, showed partial dehyscence of the suture in the third postoperative day in one animal of 
group $\mathrm{C}$ and on the fourth postoperative day in two animals (groups A and D). The presence of infection on the skin adjacent to the incision, with the presence of purulent and fetid odor, was seen on the seventh postoperative day in two animals of group D, characterizing pyodermatitis. Abcess formation was identified under unarmed eye on the seventh postoperative day in six animals of group A, eigth animals of group B and

TABLE 1 - Histopathological evaluation of surgical wound. Classification of neutrophilic infiltrate

\begin{tabular}{|c|c|c|c|c|c|c|}
\hline \multirow[t]{2}{*}{ Group } & \multicolumn{2}{|c|}{ Mild } & \multicolumn{2}{|c|}{ Moderate } & \multicolumn{2}{|c|}{ Severe } \\
\hline & $\mathbf{N}$ & $\%$ & $\mathbf{N}$ & $\%$ & $\mathbf{N}$ & $\%$ \\
\hline A & 24 & 60 & 2 & 5 & 14 & 35 \\
\hline B & 11 & 27.5 & 1 & 2.5 & 28 & 70 \\
\hline C & 18 & 45 & 20 & 50 & 2 & 5 \\
\hline D & 20 & 50 & 5 & 12.5 & 15 & 37.5 \\
\hline
\end{tabular}

${ }^{*} \mathrm{p}=0.00000 \ldots$

TABLE 3 - Histopathological evaluation of surgical wound. Classification of lymphocytic infiltrate

\begin{tabular}{|c|c|c|c|c|c|c|}
\hline \multirow[t]{2}{*}{ Group } & \multicolumn{2}{|c|}{ Mild } & \multicolumn{2}{|c|}{ Moderate } & \multicolumn{2}{|c|}{ Severe } \\
\hline & $\mathbf{N}$ & $\%$ & $\mathbf{N}$ & $\%$ & $\mathbf{N}$ & $\%$ \\
\hline A & 3 & 7.5 & 34 & 85 & 3 & 7.5 \\
\hline B & 10 & 25 & 14 & 35 & 16 & 40 \\
\hline C & 10 & 25 & 28 & 70 & 2 & 5 \\
\hline D & 14 & 35 & 21 & 52.5 & 5 & 12.5 \\
\hline
\end{tabular}

${ }^{*} \mathrm{p}=0.00000380$

TABLE 5 - Histopathological evaluation of surgical wound. Presence of granulation tissue

\begin{tabular}{llclll}
\hline \multirow{2}{*}{ Presence } & \multicolumn{2}{c}{ Yes } & & \multicolumn{2}{c}{ No } \\
\cline { 2 - 3 } \cline { 5 - 6 } & $\mathbf{N}$ & \% & & N & \% \\
\hline Group A & 39 & 97.5 & & 2.5 \\
Group B & 40 & 100 & & 0 & 0 \\
Group C & 40 & 100 & & 0 & 0 \\
Group D & 40 & 100 & & 0 & 0 \\
\hline Total \% & 159 & 99.4 & 0 & 0.6 \\
\hline
\end{tabular}

$\mathrm{p}=0.38872525$

TABLE 7 - Histopathological evaluation of surgical wound. Presence of foreign body granuloma

\begin{tabular}{llllll}
\hline Presence & \multicolumn{2}{c}{ Yes } & & \multicolumn{2}{c}{ No } \\
\cline { 2 - 3 } \cline { 5 - 6 } & N & \% & & N & \% \\
\hline GroupA & 19 & 47.5 & & 21 & 52.5 \\
Group B & 34 & 85 & & 6 & 15 \\
Group C & 29 & 72.5 & & 11 & 27.5 \\
GroupD & 22 & 55 & & 18 & 45 \\
\hline Total \% & 104 & 65 & & 56 & 35 \\
\hline
\end{tabular}

${ }^{*} \mathrm{p}=0.00168107$ four animals of group D. No animal in group C presented abcess formation visible to the unarmed eye. For microscopic analysys, five histological slices of each animal were analyzed, totalling 40 slices per group and a total of 160 histological slices in this study (Figures 5 to 9). All animals in all groups presented edema, vascular proliferation and congestion upon microscopic examination of the skin.

TABLE 2 - Histopathological evaluation of surgical wound. Classification of macrophage infiltrate

\begin{tabular}{ccccccccc}
\hline Group & \multicolumn{2}{c}{ Mild } & & \multicolumn{2}{c}{ Moderate } & & \multicolumn{2}{c}{ Severe } \\
\cline { 2 - 3 } \cline { 8 - 9 } & $\mathbf{N}$ & $\mathbf{\%}$ & & $\mathbf{N}$ & $\mathbf{\%}$ & & $\mathbf{N}$ & $\mathbf{\%}$ \\
\hline A & 7 & 17.5 & & 23 & 57.5 & & 10 & 25 \\
B & 10 & 25 & & 11 & 27.5 & & 19 & 47.5 \\
C & 10 & 25 & & 28 & 70 & & 2 & 5 \\
D & 15 & 37.5 & & 20 & 50 & & 5 & 12.5 \\
\hline
\end{tabular}

${ }^{*} \mathrm{p}=0.00000380$

TABLE 4 - Histopathological evaluation of surgical wound. Presence of young fibrosis

\begin{tabular}{lrllll}
\hline Presence & \multicolumn{2}{c}{ Yes } & & \multicolumn{2}{c}{ No } \\
\cline { 2 - 3 } \cline { 2 - 3 } & N & \% & & N & \% \\
\hline Group A & 24 & 60 & & 16 & 40 \\
Group B & 16 & 40 & & 24 & 60 \\
Group C & 9 & 22.5 & & 31 & 77.5 \\
Group D & 22 & 55 & & 18 & 45 \\
\hline Total \% & 71 & 44.4 & & 89 & 55.6 \\
\hline *p $=0.00311618$ & & & &
\end{tabular}

TABLE 6 - Histopathological evaluation of surgical wound. Presence of fibroblast proliferation

\begin{tabular}{llllll}
\hline Presence & \multicolumn{2}{c}{ Yes } & & \multicolumn{2}{c}{ No } \\
\cline { 2 - 3 } \cline { 5 - 6 } & N & \% & & N & \% \\
\hline Group A & 40 & 100 & & 0 & 0 \\
Group B & 40 & 100 & & 0 & 0 \\
Group C & 40 & 100 & & 0 & 0 \\
Group D & 39 & 9.5 & & 1 & 2.5 \\
\hline Total \% & 159 & 99.4 & & 0 & 0.6 \\
\hline
\end{tabular}

$\mathrm{p}=0.38872525$

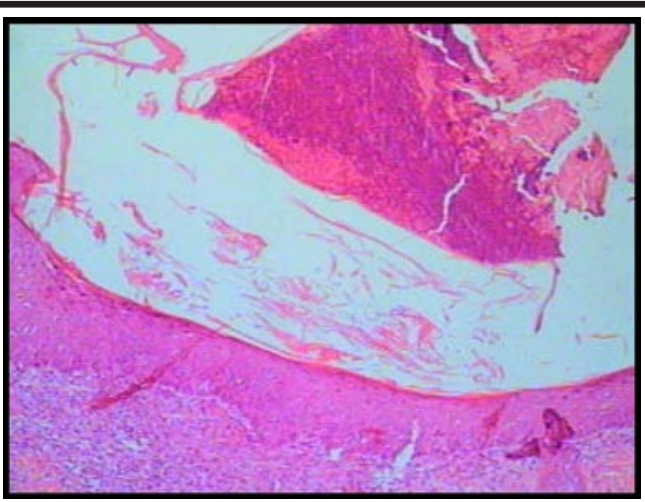

FIGURE 5 - Photomicrography with 4X lens (40X enlargement) of histological slice taken from the skin of a group $\mathrm{C}$ rat, stained with HE, Showing crust on the surface and complete epithelialization 


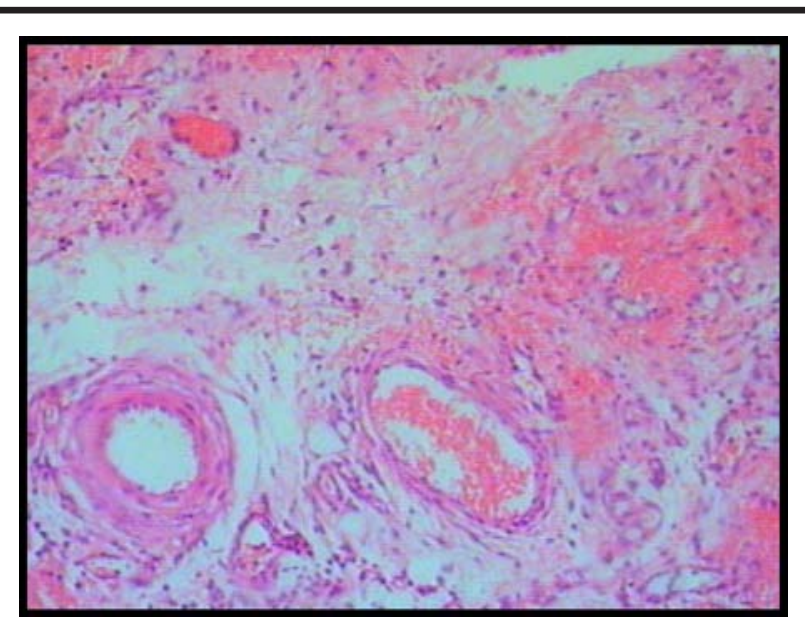

FIGURE 6 - Photomicrography with $4 \mathrm{X}$ lens (40X enlargement) of histological slice taken from the skin of a group $\mathrm{C}$ rat, stained with HE, showing stroma with edema, loose connective tissue and neovessels

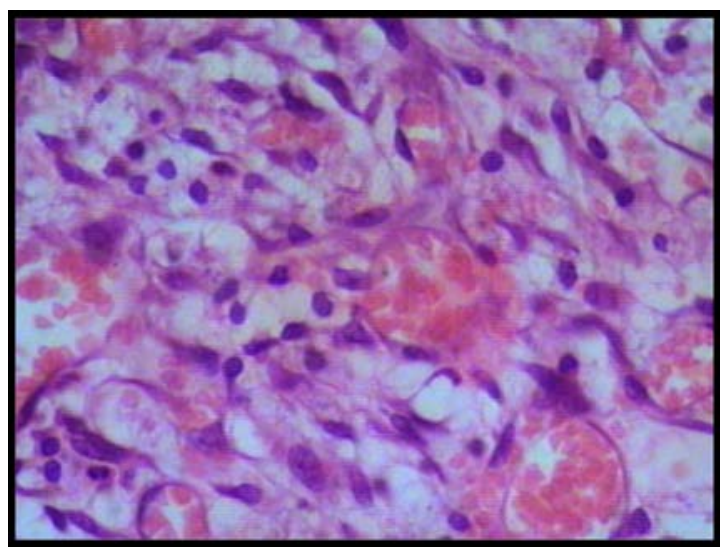

FIGURE 8 - Photomicrography with 40X lens (400X enlargement) of histological slice taken from the skin of a group D rat, stained with HE, showing detail of granulation tissue with neovessels

\section{Discussion}

Wound healing is a dynamic process involving biochemical and physiological phenomena which behave in a harmonious way in order to ensure tissue restoration. The main factor which triggers healing is the local lesion with or without tissue loss, from which physiological events completely turn towards repairing that which caused damage to the integrity of the organism. ${ }^{1}$ Tissue loss may completely or incompletely affect the corium, or the whole organ, reaching subcutaneous cellular tissue. That is what wound definition stems from. In partial-thickness wounds incomplete corium - repair takes place through the reepithelialization of epithelial annexes or epithelium originated from the unaffected adjacent skin, resulting in an almost imperceptible scar. On the other hand, fullthickness wounds - complete corium or extended to subcutaneous cellular tissue - require the formation of new tissue, called granulation tissue. Epithelialization, basis for

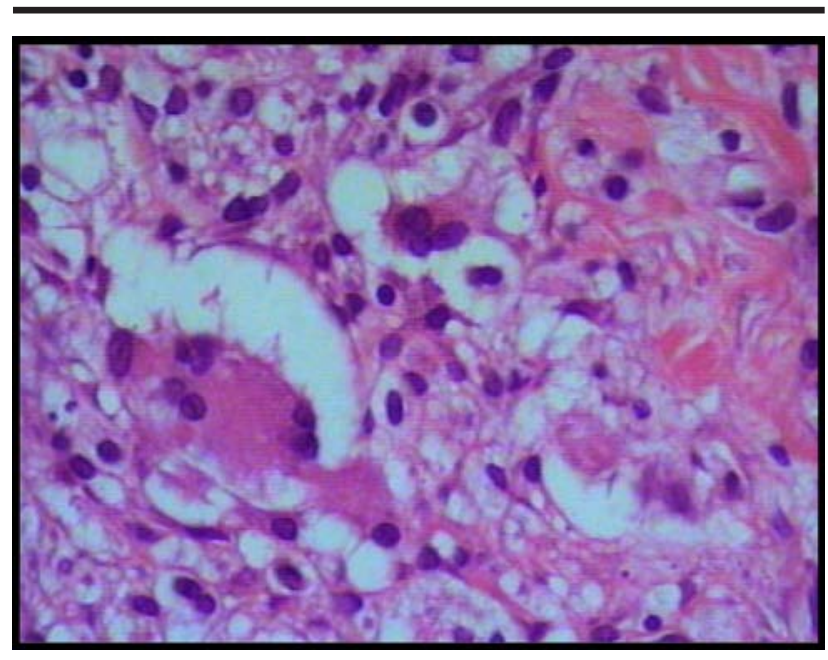

FIGURE 7 - Photomicrography with 40X lens (400X enlargement) of histological slice taken from the skin of a group $\mathrm{C}$ rat, stained with $\mathrm{HE}$, showing giant foreign body cells and lymphocytic infiltrate

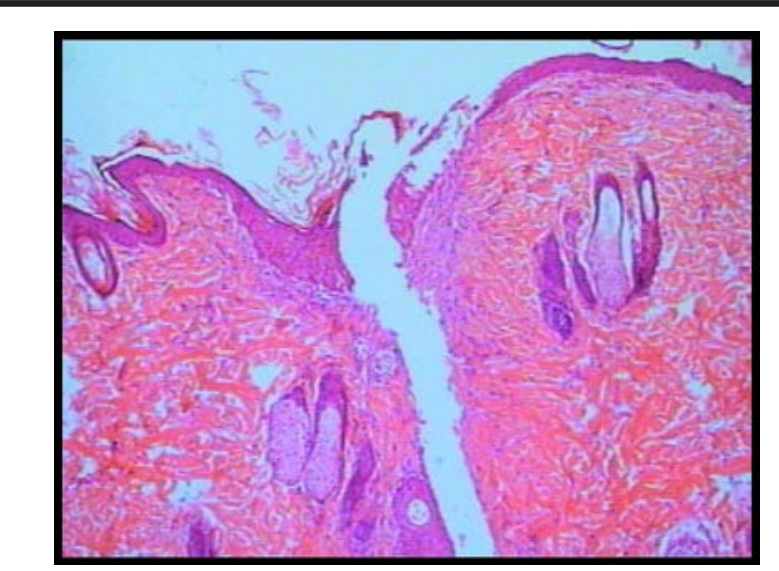

FIGURE 9- Photomicrography with 4X lens (40X enlargement) of histological slice taken from the skin of a group D rat, stained with HE, showing absence of complete epithelialization after 7 days

the healing of partial-thickness wounds, takes place only on the wound edges. In this case, scarring is totally perceptible and, many times, strongly marked. ${ }^{1}$ In a clean surgical incision, neutrophils appear within 24 hours. There is thickening of the epidermis on the incisional edge, resulting from basal cell mitosis. Within 24 to 48 hours, a continuous thin epithelial layer is formed right under the superficial crust, resulting from the migration and growth of epithelial cells. Up until the third day neutrophils are, in their majority, replaced by macrophages which will reach their peak at 10 days. Granulation tissue invades the incision, with the appearance of collagen fibers on the incisional edges. By the fiveth day the incisional space is filled by granulation tissue. ${ }^{26}$ From the seventh day on there is fibroblast proliferation and continuous accumulation of collagen, with the disappearance of most of the leucocyte infiltrate, the edema and the increased vascularization. The scar becomes pale due to the presence of collagen. In the clean surgical wound, maximum neovascularization takes 
place at five days. Collagen becomes abundant and epidermial architecture is recovered, with superficial keratinization. At the end of the first month the scar is represented by connective tissue free of inflammatory infiltrate. Many variables, both general as well as local, influence the long and complex healing process. With the evolution of hospital infection control studies, the role of endogenous and exogenous factors which lead to such problem has become evident, which caused antisepsis to become a rational measure rather than a questionable one. ${ }^{17}$ Out of the general factors which interfere in healing some may be highlighted, such as age, nutritional status, the existence of disease (such as diabetes), cardiocirculatory and coagulation alterations, systemic infectious conditions and the use of systemic drugs. Some of the local factors which interfere in healing are the surgical technique, the formation of hematomas, reaction to foreign bodies, infection and the use of topical drugs. ${ }^{1,26}$ In this study we have tried to standardize the animal samples in such a way that the variables which might interfere with the healing process would be the same. All animals had approximately the same age, were fed the same diet, operated on by the same researcher, exposed to the same quantity and quality of inoculum, with the surgical wound being sutured with the same type thread and equal number of stitches. The use of different topical agents to clean the wounds was the only variable under study. The resulting slides were analyzed by the same researcher who did not know which experimental group they belonged to, thus avoiding variations in their result. The rat was the experimental animal of choice because of factors such as easy obtention, handling and maintenance aside from a lesser morbidity and mortality, as they are animals of proven strength, even in an adverse environment. ${ }^{27}$ Another advantage in the use of rats is the smaller amount of elastic fibers found on the corium $^{28}$, since there was no interest in the study of collagen, allowing researchers to study the greater or lesser inflammatory process depending on the antisseptic agent envolved. In this experimental model the choice was to conduct the suture in all animals, in order to protect the spot from other bacteria which the wound might get in contact with otherwise, and to have a better correlation with what happens in the daily routine of human emergency wards. Nevertheless, the suture is known to contribute with the appearance of infection. It serves as a mechanical deposit for bacteria and also as an irritating factor. The mechanical aspect of suture strain also favors the onset of infection. ${ }^{2}$ The presence of a foreign body, in this case the suture, significantly decreases the number of germs causing local infection, a fact which has been proven by Elek. ${ }^{24}$ The standard inoculum used in this study has been previously tested. Preliminary studies carried out by $\mathrm{Elek}^{24}$ and Roettinger et $\mathrm{al}^{25}$ showed that the inoculation of $10^{9}$ bacteria per ml of suspension, done on the dorsum of laboratory animals, causes the appearance of $100 \%$ infection. Both PVP-I and chlorhexidine have different antisseptic properties. Saline solution, however, despite not being an antisseptic, shows to be efficient in the treatment of the infected wound. This leads us to believe that, whatever solution is employed, the main thing is to allow for a good irrigation with enough volume and pressure to cause the mechanical removal of fibrin, debris, bacteria and secretion from the wound surface. ${ }^{29}$ The PVP-I and the chlorhexidine used in this study were aquous solutions, known as degerming solutions. The presence of alcohol in the composition of these products would interfere negatively in tissue regeneration since, when applied locally, it promotes cell damage, precipitating and dehydrating its protoplasm. ${ }^{17}$ Contact between surgery and these antiseptic agents takes place in a direct and indirect way, as both PVPI and chlorhexidine have residual action following antisepsis. ${ }^{17}$ PVP-I has been synthetized in 1953, being broadly used as a surgical antisseptic, at the concentration of $1 \%$, since then called povidine ${ }^{\circledR}$. Its active principle is free iodine, presenting bacteriostatic action at the concentration of $6.4 \%$ and bactericide action at $9.6 \%$, with regards to Staphylococcus aureus. The concentration used in this study was $10 \%$, aquous solution, avoiding the citotoxic effects presented by alcohol. ${ }^{30}$ Many authors agree that the use of iodine substances causes tissue damage and question their indication in the prophylaxis of wound infection. This is due to the fact that the PVP-I solution has, in its composition, a non-ionic surfactant which provides more adherence to the surface on which it is employed, allowing for the release of iodine during a longer period, which increases the length of its antimicrobial action. ${ }^{17}$ With the wide use of PVP-I in the treatment of contaminated wounds, results as to its influence on healing and antibacterial effect are still controversial. We have tried to evaluate its effect on wounds contaminated with Staphylococcus aureus and Streptococcus pyogenes as compared to the utilization of chlorhexidine and saline solution, on lab rats. Macroscopic evaluation of surgical wounds, conducted on the seventh postoperative day, under unarmed eye, showed the formation of abcesses in $75 \%$ of untreated animals, $100 \%$ of animals treated with saline solution and $50 \%$ of those treated with chlorhexidine. Abcess formation in the animals treated with PVP-I was not verified under unarmed eye on the seventh postoperative day. This suggests that the group treated with PVP-I had greater protection against bacteria or had a slower inflammatory process, thus delaying the organization of collections. Nevertheless, this was the group which, on the seventh postoperative day, presented two animals (25\%) with purulent secretion of fetid odor on the skin adjacent to the surgical incision, characterizing pyodermatitis (folliculitis?). This was not observed in any other animal in this study. In all histological slices analyzed in this study, out of all groups, the presence of edema, vascular proliferation and congestion was observed, important events in the inflammatory response and wound healing, be they contaminated or not. Upon analyzing the group which did not undergo any type of treatment, the presence of a mild neutrophilic infiltrate is observed, as well as moderate macrophage and lymphocytic infiltrate. This characterizes an inflammatory process which is becoming chronic, most likely due to the infection which perpetuates cell damage. This is the representaion of the natural evolution of an untreated infected wound in Wistar rats. Group B, on the other hand, treated only with saline solution, shows a severe neutrophilic, macrophage and lymphocytic infiltrate. Saline solution certainly influences the healing process 
somehow, perhaps due to the mechanical action caused by its pressure and volume which ends up dragging off debris and cells, but basically diluting and distributing the inoculum inside the wound. The group of animals treated with chlorhexidine presented a moderate neutrophilic infiltrate, accompanied by macrophages and lymphocytes in moderate quantity as well. The animals treated with PVP-I showed a predominantly mild neutrophilic infiltrate, accompanied by macrophages and lymphocytes in moderate quantity. This was the group which was closer to the outcome observed on the animals which had no substance interfering on the healing process other than the infection itself. The presence of a moderate to mild lymphocytic infiltrate in all slices studied, in all groups, leads us to think about a chronification of the inflammatory process, problably due to the infection present in all animals, which perpetuates cell damage. Edema did not disappear in the slices studied. After seven days, it was observed that groups A (untreated) and D (treated with PVP-I) were the ones which presented a healing outcome which was most similar to the natural history, with a predominance of a mild neutrophilic infiltrate, moderate macrophage and lymphocytic infiltrate and presence of granulation tissue. The healing of full-thickness wounds, produced in this study, requires the formation of new tissue, the granulation tissue, and re-epithelization occurs from the edges to the center of the wound. On all slices analyzed, after the seventh day, there was presence of granulation tissue, except for one slice from group A. Nevertheless, the absence of granulation tissue in only one slice, out of the 160 total, was not statistically significant, $p$ $>0.05$. Several authors demonstrate the citotoxic effect of PVP-I at $10 \%$ over fibroblasts. ${ }^{17,30}$ In this study there was fibroblast proliferation in all slices analyzed, except for one slice in group D, treated with PVP-I.. However, this piece of data was not statistically significant, $\mathrm{p}>0.05$. These authors have demonstrated a more intense inflammatory process and a slower regeneration when PVP-I is used as compared to saline solution and chlorhexidine. ${ }^{17,30}$ The result of the present study demonstrates that tissue repair and healing took place more rapidly in the untreated group, followed by the group treated with PVP-I, then saline solution and lastly the group treated with chlorhexidine. The parameter used to determine the speed of healing was the presence of young fibrosis. Its absence was considered to be a delay in the healing process. In all slides studied there is fibroblast proliferation. The presence of foreign body granuloma was most observed in the slides feom group B (85\%), followed by group C (72.5\%), D (55\%) and A (47.5\%), a result considered to be statistically significant $(p=0.00168107)$. This foreign body granuloma formed around the suture thread and was present in all surgical wounds studied. However, this result is pure chance. All animals had the same number of stitches with the same type thread. The formation of this granuloma around the suture thread is known to be inevitable. The fact that this granuloma was not observed on some slides was due to their section levels which, by chance, may or may not go over the exact spot where the suture thread was present.

\section{Conclusions}

1. Groups A e D showed, on the seventh postoperative day, an inflammatory infiltrate with neutrophils (polymorphonuclear) in mild quantity and an infiltrate with macrophages and lymphocytes (mononuclear) in moderate quantity;

2. Group B showed, on the seventh postoperative day a severe infiltrate of neutrophils, macrophages and lymphocytes;

3. Group C showed, on the seventh postoperative day a moderate infiltrate of neutrophils (polymorphonuclear), macrophages and lymphocytes (mononuclear);

4. Group D was the one which showed an inflammatory infiltrate that was most similar to that of the untreated group. This suggests that PVP-I was the substance which least interfered with the natural evolution of the inflammatory process.

\section{References}

1. Mandelbaum SH, Santis EPD, Mandelbaum MHS. Cicatrização: conceitos atuais e recursos auxiliares. An Bras Dermatol. 2003; 8(4): 8-18.

2. Souza Filho ZA, Repka JC, Appel L, Canelo G, Fonseca O. Estudo comparativo do ágar com a solução salina isotônica no tratamento de feridas infectadas, em cobaias. Acta Cir Bras. 1997; 12(3): 169-72.

3. Knutson RA. Merbitz LA. Creekmore MA. Snipes HG. Use of sugar and povidone-iodine to enhance wound healing: five year's experience. South Med J. 1981; 74(11):1329-35.

4. d'Acampora AJ, Ortellado DK, Schemes KE, Cútulo LRA. Um pouco da história e evolução da medicina. Rev Ciênc Saúde. 2002; 20(1): 65-7.

5. d'Acampora, A.J. Infecção em cirurgia. Arq Cat Med. 1994; 23(1): 55-7.

6. Kaysinger KK. Nicholson NC. Ramp WK. Kellam JF. Toxic effects of wound irrigation solutions on cultured tibiae and osteoblasts. J Orthop Trauma. 1995; 9(4):303-11.

7. Serikawa S. Ito S. Hatta T. Kusakari N. Senna K. Hiramune T. Kikuchi N. Yanagawa R. Protection from caseous lymphadenitis in sheep by spraying iodine tincture on shearing wounds. J Vet Med Sci. 1994; 56(2):411-2.

8. Swaim SF. Bandages and topical agents. Vet Clin North Am. 1990; 20(1):47-65.

9. Rashidy AA. Fox LK. Gay JM. Diagnosis of Staphylococcus aureus intramammary infection by detection of specific antibody titer in milk. J Dairy Sci. 1992; 75(6):1430-5.

10. Molloy RG. Brady MP. A modified technique of delayed primary closure using a povidone iodine wick: influence on wound healing in an experimental model. Ir J Med Sci. 1993; 162(8):297-300.

11. Kjolseth D. Frank JM. Barker JH. Anderson GL. Rosenthal AI. Acland RD. et al. Comparison of the effects of commonly used wound agents on epithelialization and 
neovascularization. J Am Coll Surg. 1994; 179(3):305-12.

12. Kashyap A. Beezhold D. Wiseman J. Beck WC. Effect of povidone iodine dermatologic ointment on wound healing. Am Surg. 1995; 61(6):486-91.

13. Reid AB. Stranc MF. Healing of infected wounds following iodine scrub or CO2 laser treatment. Lasers Surg Med. 1991; 11(5):475-80.

14. Goebel ME. Drez D Jr. Heck SB. Stoma MK. Contaminated rabbit patellar tendon grafts. In vivo analysis of disinfecting methods. Am J Sports Med. 1994; 22(3):387-91.

15. De Wet PM. Rode H. Cywes S. Bactericidal efficacy of 5 per cent povidone iodine cream in Pseudomonas aeruginosa burn wound infection. Burns. 1990; 16(4):302-6.

16. Kai MS. Comparação dos efeitos do uso do Povidine $10 \%$ e da solução salina isotônica no tratamento de feridas contaminadas: estudo experimental [Mestrado]. Curitiba: Universidade Federal do Paraná; 1993.

17. Filho OM, Okamoto T, Garcia IG, Aranega A, Dezan E. Biocompatibilidade das soluções de iodo polivinilpirrolidona (PVP-I) e clorexidina: estudo histológico em ratos. Rev Odontol. UNESP 1998; 5(3): 9-16.

18. Howell JM. Dhindsa HS. Stair TO. Edwards BA. Effect of scrubbing and irrigation on staphylococcal and streptococcal counts in contaminated lacerations. Antimicrobi Agents Chemother. 1993; 37(12):2754-5.

19. Archer HG. Barnett S. Irving S. Middleton KR. Seal DV. A controlled model of moist wound healing: comparison between semi-permeable film, antiseptics and sugar paste. J Exp Pathol. 1990; 71(2):155-70.

20. Swaim SF. Riddell KP. Geiger DL. Hathcock TL. McGuire JA. Evaluation of surgical scrub and antiseptic solutions for surgical preparation of canine paws. J Am Vet Med Assoc. 1991; 198(11):1941-5.
21. Taylor GJ. Leeming JP. Bannister GC. Effect of antiseptics, ultraviolet light and lavage on airborne bacteria in a model wound. J Bone Joint Surg Am. 1993; 75(5):724-30.

22. Severyns AM. Lejeune A. Rocoux G. Lejeune G. Nontoxic antiseptic irrigation with chlorhexidine in experimental revascularization in the rat. J Hosp Infect. 1991;17(3):197-206.

23. Osuna DJ. DeYoung DJ. Walker RL. Comparison of an antimicrobial adhesive drape and povidone-iodine preoperative skin preparation in dogs. Vet Surg.1992; 21(6):458-62.

24. Elek SD. Experimental staphylococcal infections in the skin of man. Ann N Y Acad Sci. 1956; 65: 85-90.

25. Roeitinger W, Edgerion M, Kurtz LD. Role of inoculation site as a determinant of infection in soft tissue wounds. Am J Surg. 1973; 126: 354-8.

26. Cotran RS, Kumar V, Collins T. Patologia estrutural e functional. $6^{\mathrm{a}}$ ed. Rio de Janeiro: Guanabara Koogan; 2000.

27. d'Acampora AJ. Modelo de sepse experimental em ratos: estudo clínico e histológico [Doutorado]. São Paulo: Universidade Federal de São Paulo; 1996.

28. Noronha L, Chin EWK, Kimura LY, Graf R. Estudo morfométrico e morfológico da cicatrização após uso de laser erbium: YAG em tecidos cutâneos de ratos. J Bras Patol Med Lab. 2004; 40(1): 41-8.

29. Torres AM, Cisterna MS, Vargas G, Cosignani M, Oporto V, Fuentes N, et al. Antisepticos y solucion salina en el manejo de herida operatória infectada. Bol Hosp Viña Del Mar 1986; 42(3): 164-7.

30. Ribeiro RC, Santos OLR, Moreira AM, Bacellar C, Aboim E. Interferência do uso de soluções de polivinil-pirrolidona-iodo no processo cicatricial: estudo experimental em camundongos. Folha Med. 1995; 111(1): 61-5.

\section{Correspondence:}

Armando José d'Acampora

Condomínio San Diego, casa 9

88024-420 Florianópolis - SC Brazil

Phone: (55 48)9961-0316

dacampora@gmail.com
Conflict of interest: none Financial source: none

Received: April 04, 2006

Review: May 09, 2006

Accepted: June 06, 2006

\section{How to cite this article:}

d’Acampora AJ, Vieira DSC, Silva MT, Farias DC, Tramonte R. Morphological analysis of three wound-cleaning processes on potentially contamined wounds in rats. Acta Cir Bras. [serial on the Internet] 2006 Sept-Oct;21(5). Available from URL: http://www.scielo.br/acb 